ARTICLE

\title{
Scottish Press Coverage of UK General Elections after Devolution: the 2001 and 2005 Campaigns
}

\author{
MARINA DEKAVALLA, University of Stirling
}

\begin{abstract}
This paper presents preliminary findings from a wider study into the form that political debate takes in Scottish and English/UK newspapers' reporting of the 2001 and the 2005 UK Elections. The research project aims to contribute to the discussion regarding the role played by the Scottish press in political deliberation after devolution and compares its contribution to the electoral debate with that of newspapers bought in England. This paper explores the results of a content analysis of articles from daily Scottish and UK newspapers during the four weeks of each election campaign period. This reveals that, despite some differences, the overall picture of the coverage of major election issues is consistent. A selection of the coverage of taxation, the most mentioned reserved issue in the 2001 campaign, is subsequently analysed using critical discourse analysis, and the results suggest more distinction between the two sets of newspapers.
\end{abstract}

\section{KEYWORDS}

Newspapers; General Election; Scotland; devolution; national identity.

\section{Introduction}

My research aims to examine the contribution of the Scottish press to the political debate, when reporting on Westminster election campaigns, following devolution. I am interested in whether English/UK and Scottish papers contribute in a similar way to the public debate around these elections and whether they offer their respective publics similar or different input for further processing and decision-making. The focus of my study is not on audience responses to this input, which has been examined by researchers such as Norris and Sanders (2003), but on the textual contribution itself of the newspapers to the debate.

The relationship between Scotland and the British Union has been through many stages which eventually led to the establishment of the Scottish Parliament in Edinburgh in 1999. The history of this relationship, as well as Scotland's distinctive identity within the Union, has influenced political life in Scotland today (Nairn, 1977; Devine, 1999; McCrone, 2000, 2001). Today the Scottish Parliament controls issues relevant to daily life in Scotland, such as health, education, law and order, and transport (known as 'devolved' issues). However, the financial resources invested in the above services are allocated by the Westminster government, which is also responsible for raising tax. 'Reserved' functions are controlled by the government in 
London and include foreign policy, defence, broadcasting, and macro-economics. For the electorate in Scotland therefore, devolved issues are decided in Scottish elections and only reserved matters are relevant in Westminster elections. For the electorate in England both sets of issues are decided in Westminster elections, given that England does not have its own parliament.

The role of the Scottish press in maintaining a separate Scottish identity and in contributing to the creation of a specifically Scottish public debate has been highlighted by many scholars (Macdonald, 1978; Meech and Kilborn, 1992; Smith, 1994, Schlesinger, 1998; Hutchison, 2002; Connell, 2003; Higgins, 2006). It has also been argued (McNair, 2000) that newspapers in general play an important role in defining the different interpretations an issue is going to receive in other media. For these reasons, the coverage of elections by the Scottish press is of particular interest in my study.

On the other hand, the complex relationship between state and nation in the UK makes the 'branding' of any newspaper as 'national' problematic. As MacInnes et al. note, 'national' can be defined in different ways in different parts of the UK (for example it can be understood as meaning British, Scottish or Welsh), newspapers which claim to be national often are bought by a geographically restricted readership and different readers may perceive national boundaries in different ways (2007, p.191-193). For the purposes of my comparison, I refer to newspapers published in Scotland and targeting a Scottish audience as 'Scottish' and I compare them to newspapers published in England and targeting an English audience or an audience living across the UK state, which I refer to as 'English/UK' papers.

The press coverage of the two first elections to the Scottish Parliament has been studied by research institutes and individual academics. For example, Higgins (2004a, $2004 \mathrm{~b}$ and 2006) evaluated the contribution of the press to the public debate around the 1999 election and found a quantitatively and qualitatively distinct contribution by the Scottish press. The Institute of Governance at the University of Edinburgh (2003) published a comprehensive quantitative analysis of the coverage of the 2003 Scottish election which again showed a stronger contribution to the debate by the Scottish papers.

Research on press coverage of general elections after devolution has tended to focus on English and UK titles (for example, Butler and Kavanagh, 2002; Scammel and Harrop, 2002), where Scottish titles were either not fully represented or not analysed in detail. Research on the Scottish coverage of these elections has provided descriptions of some of the issues mentioned by Scottish papers, without presenting a systematic quantitative or qualitative analysis (e.g., Kellas, 2002; the Constitution Unit, 2001).

\section{Aims and methods}

Previous research has therefore established the distinctiveness of the Scottish press coverage of Scottish Parliamentary elections. My own research seeks to examine if the same holds when the political event covered is a UK election. The aim of my project is therefore to contribute to a better understanding of the role of the Scottish 
press in political debate after devolution, by examining the way it operates in the context of a British rather than a Scottish political context. I am interested in whether the election coverage takes the same form on both sides of the border or whether each audience receives different information in quantitative and qualitative terms - whether there is a specifically Scottish way of talking about a UK political event in which the Scottish electorate still participates.

The research is a detailed comparison of election coverage of the 2001 and 2005 General Election campaigns in five Scottish newspapers (The Scotsman, the Herald, the Daily Record, the Aberdeen Press and Journal and the Dundee Courier), five English and UK titles (The Guardian, the Daily Telegraph, the Daily Mail, the Sun and the Daily Mirror) and two Scottish editions of English papers (the Scottish Sun and the Scottish Daily Mail). All the papers studied are daily morning titles and the sample is balanced with regards to the categories (quality, middle market and popular) and the political orientation (right or left of the centre) of the newspapers included.

In order to achieve a representative view of the debate in the Scottish press, I have included titles from both the central belt and from more Northern regions of Scotland. Central belt titles, and especially the Scotsman and the Herald claim national status in Scotland by expressing 'a sense of nationhood, as opposed to mere regionality' (Meech and Kilborn, 1992, p.258). The Aberdeen Press and Journal and the Dundee Courier do not claim national status, however their circulation figures are comparable to those of the Scotsman and the Herald (www.abc.org.uk). In fact both groups of papers tend to have their main readership based in their respective areas (Hutchison, 2002).

My purpose is to compare how these newspapers provide their readers with political information and views about the election. I am using content analysis in order to identify general patterns in the coverage, such as the amount of coverage dedicated to the election by Scottish and English/UK papers, the type of coverage (news, editorial, opinion or readers letters), as well as the main election issues mentioned in each sample for each election period. I then choose the most mentioned reserved and the most mentioned devolved issue for each period and use critical discourse analysis to examine the way the English/UK and the Scottish sample contributed to the debate around it. The final stage of my research will involve a small number of interviews with political editors writing for the Scottish papers at the time, which will complement the interpretation of my other findings. This paper presents preliminary results from the content analysis of the election coverage as well as of the critical discourse analysis of the issue of taxation, the most mentioned reserved issue in 2001.

The reason for using both quantitative and qualitative methods to study the contribution of the Scottish press to the political debate is that although content analysis can illustrate trends and quantitative characteristics for a large number of texts, it cannot achieve the deeper-level insights offered by qualitative textual analysis (VanDijk, 1983; Deacon et al., 1999). A combination of the two methods captures similarities and differences in the coverage of the English/UK and the Scottish sample both in how much they talked about the elections as well as in how they talked about them. 
The content analysis of my data therefore presents a comprehensive picture of the election coverage in the two samples and the patterns they follow, while at the same time it helps to identify the issues whose coverage is to be sampled in the discourse analysis. The discourse analysis on the other hand discusses the representation of one of these issues, that of taxation, in the two groups of newspapers and examines whether it is presented as relevant to a nationally identified public. Such qualitative distinctions would not be possible to make through content analysis.

\section{Sample}

The newspaper articles for the analysis were retrieved from the Lexis-Nexis on-line database and include all the election coverage in these titles, starting from the day after the official announcement of the election date, and ending on the day of the election. It has often been argued that this electronic database is problematic as a resource for research. One of the most comprehensive evaluations of the database's weaknesses can be found in an article by David Deacon (2007) whose conclusion is that there are several issues to take into consideration when planning a project based on material from Lexis-Nexis, such as random omissions in the database, the problem of identifying keywords which will deliver all the relevant coverage and the possibility of getting articles which are not relevant to the topic studied.

I have used the points made by Deacon (2007) when planning my sampling. I tested different keywords to retrieve relevant coverage, and the ones that I found to be most effective were 'election' and 'vote' - therefore all the articles that contain either of these or their derivatives have been included in the analysis. All the material has been read to ensure that any double-entries or articles which are irrelevant to the British elections are deleted. Part of the data has been double-checked against hard copies and this did not seem to alter the trends that were initially found in the electronic data (even though more articles were added). This confirms Deacon's conclusion that any omissions in the database are random and not systematic.

During the analysis, I discovered that although Lexis-Nexis includes the Scottish editions of English newspapers, their records are weak compared to the other titles and items that appear in both editions are not annotated as such. I have therefore cross-checked the coverage of the Scottish Sun and the Scottish Daily Mail against hard copies. The data from the Dundee Courier consisted entirely of hard copy, as the paper is not available on the database. I also discovered weaknesses in the database's recording of readers' letters, which is something I took into consideration in the analysis of my results.

The amount of data to be considered is such that a study of hard copies would not have been feasible. Reducing the sample of data, on the other hand, would not have allowed representative conclusions about the contribution of the Scottish press to the electoral debate to be drawn. It was therefore decided that using Lexis-Nexis would be the best means to conduct the analysis, while at the same time remaining alert for any irregularities. 
As mentioned above, this paper is based on the results of the content analysis of the material from both election periods as well as those of the discourse analysis of the issue of taxation, which was the most mentioned reserved issue in the 2001 campaign.

I start by looking at the content analysis results and by giving an overall picture of the amount and the distribution of the coverage in the Scottish and the English/UK sample. I then move to look at the coverage dedicated to devolved and reserved issues by each sample. Following that, I examine similarities and differences between individual titles in each group of newspapers. My content analysis finds more similarities than differences in the amount and distribution of the coverage in the two samples and a similar level of prominence given to key issues. The quantitative analysis therefore suggests a similar contribution of the two samples to the debate on devolved and reserved issues because the same issues are mentioned most in both sets of newspapers.

After the presentation of my quantitative results, I discuss briefly some initial findings of the critical discourse analysis of the issue of taxation in the 2001 General Election campaign. These suggest that although taxation was the most mentioned reserved issue of the election in both samples, there are differences in the way the Scottish and the English/UK papers discuss this issue and relate it to the interests of their respective audiences.

\section{Content analysis: overall patterns of coverage}

It has been argued (Higgins, 2006) that the press can contribute to the political debate at elections by providing a large quantity of coverage (both informative and evaluative), especially at the time preceding the election date, when it can be used by the electorate directly to inform political action; by providing a high proportion of opinion coverage; and by placing election coverage in the first pages of the newspaper. I therefore looked at how each sample performed based on these criteria.

In both election periods the seven Scottish papers dedicated on average less space to the campaign than the five English/UK titles. In 2001 the five English/UK papers had approximately half $(50.9 \%)$ of the total election coverage, while the seven Scottish titles had 49.1\%. In 2005 the gap was wider, as the English/UK papers had $57.7 \%$ of the coverage while the Scottish papers dedicated on average about 130,000 words less than the UK ones (see table 1).

Table 1.

\begin{tabular}{|l|l|l|l|}
\hline & Total & Scottish titles (7) & UK titles (5) \\
\hline Overall coverage 2001 & \multicolumn{3}{|l|}{} \\
\hline Number of words & $2,717,865(100 \%)$ & $1,333,089(49.1 \%)$ & $1,384,776(50.9 \%)$ \\
\hline Overall coverage 2005 & $2,367,191(100 \%)$ & $1,001,576(42.3 \%)$ & $1,365,615(57.7 \%)$ \\
\hline Number of words &
\end{tabular}


The difference in the amount of coverage between the two samples was found to be statistically significant in both election periods, using a General Linear Model test. The drop in the overall Scottish coverage in 2005 compared to 2001 however was not statistically significant because it was due to a dramatic drop in the coverage of just two newspapers, namely the Scotsman and the Herald. As mentioned above though, these two titles are often perceived to be 'national' Scottish newspapers and are hence considered as key opinion leaders on politics in Scotland.

In both samples, the majority of the coverage consisted of news items. I am using the term news to identify informative material that does not openly express the opinion of the author or the newspaper (although it may not be entirely opinion-free) and the terms opinion and leader to identify more openly evaluative content. Opinion items include opinions of regular or guest contributors and leader items express the official view of the newspaper.

A third type of evaluative content is readers' letters, which could potentially demonstrate the contribution of readers to the debate in the press - even though Pounds (2006) has found strong editorial control based on commercial criteria in the selection of readers' letters that appear in newspapers in Britain. However, the recording of readers' letters by Lexis-Nexis was found to be unreliable in several titles during the cross-checking of the material I carried out. It was hence not possible for me to compare the distribution of this type of evaluative material successfully.

The overall distribution pattern of informative and evaluative material was the same in the two samples in both periods, even though there were small differences in the balance between different types of evaluative material (leaders, opinion articles and readers' letters).

So far the analysis suggests that on average the Scottish papers dedicated less space to the campaign, yet they offered a similar distribution of informative and evaluative material.

When I looked at the distribution of different types of material across the four weeks of the campaign, my analysis found that in 2001 both samples increased their news coverage in the final week, while the English/UK sample also increased its evaluative coverage during that week, perhaps assisting its readers to make an informed decision just before the vote or because the election day became more imminent then. In 2005, the patterns followed by the two samples were similar to each other, but difficult to interpret in a meaningful way. Front-page coverage of the election is generally similar in the two samples in 2001, while in 2005, the English/UK titles featured more items on the first page.

In conclusion, I have found so far that in both election years studied, the Scottish press had less election coverage than the English/UK papers and even more so in 2005, but in general the overall balance between informative and evaluative material was consistent in the two samples. The drop in the Scottish coverage in 2005 was mainly due to a reduction of the coverage of the Scotsman and the Herald and was also accompanied by a drop in first-page coverage. 


\section{Content analysis: election issues}

Turning now to the election issues covered, I have separated these into devolved and reserved issues. As mentioned earlier, devolved issues in Scotland are not decided during Westminster Elections, while reserved issues are. In my analysis I counted mentions of issues because often the same article mentions more than one issue at the same time. I then compared the number of mentions devolved issues received in relation to each other in each sample and repeated the same procedure for reserved issues.

This part of the analysis revealed that despite differences in the actual number of mentions, the order of prominence of the issues (in relation to each other) was very similar in the two samples. For example, in 2001 the four most mentioned devolved issues in both samples were health, education, law and order, and public spending, in the same order. In 2005 the four most mentioned reserved issues in the Scottish sample were the Iraq war, taxation, the economy, and immigration, while in the English/UK sample these were the Iraq war, taxation, immigration and the economy. Any minor differences in the order of prominence of different issues between the samples were found not to be statistically significant.

The comparison of the prominence given to different election issues also helped me identify the most mentioned devolved and the most mentioned reserved issue for each period and hence define the sample for my critical discourse analysis. In 2001 the most mentioned reserved issue in both samples was taxation, while the most mentioned devolved issue was health. In 2005 the Iraq war and health were the top issues in each category for both samples. These are the four issues my critical discourse analysis will focus on, although in this paper I present only the analysis of the coverage of taxation.

Another interesting observation which came out of this part of the analysis is that in 2001 , in both samples, the most mentioned devolved issue (health) received more mentions than the most mentioned reserved issue (tax). This is particularly interesting in the case of the Scottish titles because, although health issues are not decided in this election, the papers seem to have the same pattern as the UK sample and mention health most of all other issues. The critical discourse analysis of the coverage of the two samples on health will focus on similarities and differences in the way the two samples contribute to this debate.

\section{Content analysis: the contribution of individual Scottish titles}

Finally, I examined how individual titles within each sample contributed to the debate in quantitative terms. This analysis revealed that despite the overall similarities in pattern discussed above, there are some variations in the contributions of individual Scottish titles to the debate.

As far as the overall coverage of the campaign is concerned, in 2001 the three Scottish titles with the most coverage were the Scotsman, the Herald and the Scottish Daily Mail, while in 2005 the Scotsman and the Herald reduced their election coverage 
significantly and the Scottish Daily Mail was the title with the most coverage in the Scottish sample. Among the English/UK titles, the Guardian, the Daily Telegraph and the Daily Mail had the most coverage in both 2001 and 2005, in the same order.

As far as the coverage of devolved and reserved issues is concerned, I have found a tendency for the two central belt quality titles to follow similar patterns. In both election periods, the Scotsman and the Herald seem to give similar levels of prominence to different election issues, with very few exceptions. However, the other central belt title, the Daily Record, which is a popular title, appeared a little more differentiated, often following trends seen in other popular titles. For example, in 2001 it had a higher proportion of mentions on crime and more advice on how to vote while in 2005 it had more mentions of health than the other central belt titles, more mentions of immigration and more advice on how to vote- all these trends were also found in other popular titles.

Moreover, the two Scottish editions of English papers tended to mirror the trends of their London editions in both election periods. For example, in 2005 both the Scottish Sun and the Scottish Daily Mail had tax as their second most mentioned reserved issue, in contrast to the rest of the Scottish sample, while the Scottish Sun followed the pattern of its English edition in dedicating more mentions to law and order. In 2001 both titles gave extra attention to issues like Europe and the Euro in comparison with the other Scottish titles, although they reduced the proportion of mentions compared to their London editions.

Finally, the non-central belt titles, the Aberdeen Press and Journal and the Dundee Courier, seem to deviate from the agenda of the central belt titles and often focus on issues of local importance. Fuel prices and employment score consistently higher in these titles than in the central belt ones in both election periods, while transport and the environment are also high in the Press and Journal in both periods. In 2005 both non-central belt titles had less mentions of Iraq and public spending, compared to the central belt newspapers. Some of these divergences in the non-central belt titles seem to suggest a special prominence given to geographically significant issues.

\section{Critical Discourse Analysis: taxation in the 2001 General Election campaign}

I will now move to a brief overview of the results of the critical discourse analysis on the coverage of tax, the most mentioned reserved issue of the 2001 coverage. Critical discourse analysis is concerned with how political and social ideologies and power are constructed and reproduced through discourse (Wodak, 2001, p.2-3; VanDijk, 2001, p.96). My analysis aims to reveal how the two samples and individual titles within each of them talk about the issue, how they position themselves in the debate and how they identify the relevance of the issue to their readers. These are aspects that cannot be captured by quantitative methods and therefore the qualitative part of my research complements and provides a different layer of insight into the data.

During the 2001 campaign there was significant debate in all the newspapers on the different parties' plans about taxation at the UK level. At the same time, the Scottish papers discussed the issue of fiscal autonomy, namely the possibility of the Scottish 
Parliament acquiring the power to raise its own taxes to be spent on public services in Scotland. This debate was only covered in the Scottish sample, which may on the one hand not appear surprising, but on the other hand it suggests that the English/UK papers did not find this issue to be relevant for their readers. Fiscal autonomy became prominent in the Scottish papers after a group of academics wrote a letter to the Scotsman defending the cause. The letter caused reactions by politicians and the debate expanded in the entire Scottish sample in the following days.

In order to analyse a sample that would reflect both the debate on Westminster tax (namely taxation as an issue on a UK-wide level) and the specifically Scottish debate on fiscal autonomy, I chose the coverage of $22^{\text {nd }}$ May 2001, which was one day after the letter on fiscal autonomy appeared in the Scotsman, which left time for politicians and other newspapers to react. At the same time, the debate on Westminster tax was also running in all the newspapers, with Labour and the Conservatives discussing their tax plans.

In the critical discourse analysis of this material, I looked at how taxation is represented - whether it is seen as having an effect on people's lives or on the wellbeing of the state, or whether it is just an area where different party policies compete. To examine these issues I used the concept of transitivity (Fowler, 1991), looking at the position tax typically occupies in sentences, whether it accompanies verbs which show action or state, who is presented as receiving the influence of tax, who is presented as controlling decisions about tax and which sources are cited in relation to the issue.

I also aimed to establish if the papers adopt a particularly British, English or Scottish perspective in their coverage through their use of national markers such as 'Britain', 'British' or 'Scotland', 'Scottish'. I also paid particular attention to their use of personal pronouns such as we and you to address the reader as a member of a nationally defined community (Billig, 1995; Wodak et al, 1999; Law, 2001; Rosie et al., 2004 and 2006).

In this way I aimed to establish whether the papers see tax as something relevant to their readership, whether they identify or address this readership as a nation, and if they perceive the national community affected by tax within a Scottish or a UK frame. I will briefly present here a summary of the findings of my critical discourse analysis to date.

When reporting on tax at the UK level, the Scottish Sun and the Scottish Daily Mail were the only newspapers in the Scottish sample that highlighted the effects of the issue on taxpayers, the public services, the economy or businesses. The 'indigenous' Scottish papers presented taxation merely as a battlefield of debate between the parties, and although they did take position in favour or against the participants in this debate, they did not present tax in connection with the interests of their readers as taxpayers, or with life in Scotland or the UK. This is not the case in the English/UK titles, where all of them, except for the Guardian, additionally link tax with the interests of taxpayers or with the economy.

In the entire Scottish sample, the main actors and speakers on taxation at a UK level are Westminster parties and politicians, with the exception of the Aberdeen Press and 
Journal, where local candidates are additionally quoted on the issue. The issue is generally placed within a UK framework through the use of national markers, while the coverage of the English/UK papers also presents the same features.

Turning now to look at the coverage of fiscal autonomy, which was only covered in the Scottish titles, we see that the main speakers are Scottish politicians and the 12 academics who wrote the letter to the Scotsman. No Westminster actors or speakers are present and the debate is marked as a 'Scottish' debate. The Scotsman is the only newspaper that positions itself openly in favour of fiscal autonomy and which presents the 12 academics and their views in a positive manner. The other Scottish titles do not state an explicit position through editorial coverage, but tend to present the 12 academics and their cause as biased in favour of the SNP while the discourse they use shows their opposition to fiscal autonomy.

The Scotsman presents fiscal autonomy as a force of growth for Scotland's economy, a way to strengthen the British Union and allow Scotland control over its affairs. The Herald presents it as a road that may lead to an undesirable constitutional change, while the Scottish Daily Mail as a possible financial burden for taxpayers. Perhaps more importantly though, the Scotsman and the Herald, in their opinion coverage, both address their readership as a nation within the context of fiscal autonomy. The Scotsman addresses the reader as a member of the Scottish nation and the Herald as a member of the British nation:

'That we are at the bottom of the league and struggling to achieve any growth at all must rank as the cardinal policy failure of our time.' (The Scotsman, 22/05/01, opinion article)

'Our 12 economists say fiscal autonomy is 'crucial'. But here in the UK it is inextricably linked to alternative constitutional futures.' (The Herald, 22/05/01, opinion article)

Both newspapers make use of devices which have been associated with the construction of national identity in discourse (Billig, 1995; Wodak et. al, 1999), such as location marker here and addressee-inclusive personal pronoun we to identify their readers as members of a common national community and construct a common nationhood. However, each paper identifies this national community differently. In the Scotsman's article, Scotland is a nation which is failing to achieve its economic potential and would benefit in this respect from having fiscal autonomy. The writer uses addressee-inclusive we as a 'person for country' metonym: the writer, the reader and the community of Scottish people they belong to are not literally failing to grow. Instead, we stands for the 'national body', the 'national territory' of Scotland (Wodak et al, 1999, p.47). In the Herald's article, again personal pronoun our includes the writer, the reader and the national community they belong to, though this time this community is positioned within a UK context, with the emphatic use of here in the $U K$.

Moreover, both instances of we serve as a way in which the newspapers address the readers at the same time as referring to them. They establish a common identity among the 'imaginary community' of readers (Anderson, 1983) and the writer of the article, assuming common values and beliefs among them (Tolson, 1996, p.62). Of 
course this national community is defined differently in each paper: as a Scottish community in the Scotsman and as a British community in the Herald.

I have found, therefore, that each newspaper adopts a different approach to fiscal autonomy. Whatever the view of individual papers on the issue though, in contrast to the debate on Westminster tax, here Scottish titles discuss the effects of tax on the wellbeing of citizens and the economy. Moreover, there are also instances of Scottish newspapers addressing or referring to their readers as Scottish or British citizens and constructing a common national community, something that was not the case in the Westminster tax debate. It may hence be argued that the issue of fiscal autonomy is indicative of differentiation in the Scottish press' reporting on tax, not only because it is not covered by the UK papers, but also because it presents occasions where the papers identify the national identity they are attributing to their readers when they address them as Scottish or British citizens.

\section{Conclusion}

Overall, I have shown that the quantitative contribution of the Scottish press to the debate in both election periods appears similar to that of the English/UK titles. Although the Scottish titles dedicate less space to the campaign, the distribution of informative and evaluative material is similar to that of the UK newspapers and they also follow similar patterns in the election issues they mention most. Within the Scottish sample I found differences between the agendas of the central belt and the non-central belt titles in the issues which are covered most, while the Scotsman and the Herald exhibit the same quantitative trends in most of their election coverage.

Despite these quantitative similarities between the two samples, the critical discourse analysis of the coverage of taxation has revealed differences in the way that taxation is discussed by each sample, which cannot be studied by quantitative methods. The critical discourse analysis has shown that, in contrast to the English/UK titles, the 'indigenous' Scottish newspapers do not highlight the importance of Westminster tax issues for the lives of their readers. When they focus on fiscal autonomy though, they do link taxation with life in Scotland, while the Scotsman and the Herald additionally address their readers as members of a nation, even though they construct nationhood differently: the Scotsman within a Scottish and the Herald within a UK context. However, they both construct a national community which includes their readers, and they present this community as affected by fiscal autonomy.

The analysis above seems to lead to the preliminary conclusion that, in quantitative terms, the contribution of the Scottish press to the public debate around Westminster elections after devolution is not as markedly different to that of the English/UK press as might be expected: even though the coverage in the Scottish papers is less in overall quantity, the general patterns seem similar, with just a few exceptions. Moreover the quantitative contribution of the Scottish newspapers is not homogenous and we see some differences between titles.

When looking in detail at the coverage of one of the election issues, that of taxation, we find more differentiation of the Scottish titles to the English/UK ones, providing evidence of a distinct contribution of the Scottish titles to the public debate on the 
issue: Westminster taxation is not shown to be relevant to the lives of the Scottish electorate, even though Scottish newspapers do report on the debate. Another debate topic, that of fiscal autonomy arises as a specifically 'Scottish' issue under taxation and is represented as affecting Scottish economy and the lives of the Scottish electorate. The fiscal autonomy debate also presents additional complexities regarding the way different Scottish titles address their readers as Scottish or as British citizens.

The next stages of my research will be looking at the coverage of the most mentioned reserved issue for 2005, namely the Iraq war, and the coverage of health, the most mentioned devolved issue in both election periods. In light of the findings on the issue of taxation discussed in this paper, I will look at whether similar patterns appear in the coverage of these issues or whether the case of taxation is unique in its treatment by the Scottish sample. I will also be looking at whether the devolved nature of health, and the role of the Scottish parliament in it, influences the form that the debate takes in Scotland, with regards to the representation of the issue and its relevance to Scottish voters.

\section{References}

Anderson, A. (1983) Imagined Communities: Reflections on the Origin and Spread of Nationalism. London: Verso.

Audit Bureau of Circulations: www.abc.org.uk

Butler, D. and Kavanagh, D. (2002) The British General Election of 2001. Basingstoke: Palgrave.

Billig, M. (1995) Banal Nationalism. London: Sage.

Connell, L. (2003) 'The Scottishness of the Scottish Press: 1918-39'. Media, Culture and Society, Vol. 25 pp. 187-207.

Constitution Unit, UCL (2001) Nations and Regions: The Dynamics of Devolution Quarterly Monitoring Report for Scotland - August 2001 [online], London. Available from: www.ucl.ac.uk/constitution-unit.

Deacon, D. (2007) 'Yesterday's Papers and Today's Technology: Digital Newspaper Archives and 'Push Button' Content Analysis'. European Journal of Communication, Vol. 22 (5) pp. 5-25.

Deacon, D., Pickering, M., Golding, P. and Murdock, G. (1999) Researching Communications: A Practical Guide to Methods in Media and Cultural Analysis. London: Arnold.

Devine, T.M. (1999) The Scottish Nation: 1700-2000. London: Penguin.

Fowler, R. (1991) Language in the News: Discourse and Ideology in the Press. London: Routledge. 
Higgins, M. (2004a) 'Putting the Nation in the News: the Role of Location Formulation in a Selection of Scottish Newspapers'. Discourse and Society, Vol. 15 (5) pp. 633-648.

Higgins, M. (2004b) 'The Articulation of Nation and Politics in the Scottish Press'. Journal of Language and Politics, Vol. 3 (3) pp. 463-483.

Higgins, M. (2006) 'Substantiating a Political Public Sphere in the Scottish Press: a Comparative Analysis'. Journalism, Vol. 7 (1) pp. 25-44.

Hutchison, I.G.C. (2002) 'Scottish Newspapers and Scottish National Identity in the Nineteenth and Twentieth Centuries'. In: 68th IFLA Council and General Conference, August 18-24 2002, Glasgow.

Institute of Governance, University of Edinburgh (2003) The Scottish Elections 2003 Media Content Research - Report to the Electoral Commission. [online]. Available from: www.electoralcommission.org.uk

Kellas, J.G. (2002) 'The Campaign in Scotland'. In: Butler, D. and Kavanagh, D., The British General Election of 2001. Basingstoke: Palgrave.

Law, A. (2001) 'Near and Far: Banal National Identity and the Press in Scotland'. Media, Culture and Society, Vol. 23 pp 299-317.

Macdonald, M. (1978) 'The Press in Scotland'. In: Hutchison, D. ed. Headlines: The Media in Scotland. Edinburgh, EUSPB.

MacInnes, J., Rosie, M., Petersoo, P., Condor, S. and Kennedy, J. (2007) 'Where is the British National Press?' The British Journal of Sociology, Vol. 58 (2), pp. 185206.

McCrone, D. (2001) Understanding Scotland: the Sociology of a Nation. 2nd edition. London: Routledge.

McCrone, D. (2000) 'Scotland and the Union: Changing Identities in the British State'. In: Morley, D. and Robins, K. eds. British Cultural Studies. Oxford: Oxford University Press.

McNair, B. (2000) Journalism and Democracy: an Evaluation of the Political Public Sphere, London: Routledge.

Meech, P. and Kilborn, R. (1992) 'Media and Identity in a Stateless Nation: the Case of Scotland'. Media, Culture and Society, Vol. 14 pp. 245-259.

Nairn, T. (1977) The Break-Up of Britain. London: Verso.

Norris, P. and Sanders, D. (2003) 'Message or Medium? Campaign Learning During the 2001 British General Election'. Political Communication, Vol. 20 (3), pp. 233262. 
Pounds, G. (2006) 'Democratic Participation and Letters to the Editor in Britain and Italy'. Discourse and Society, Vol. 17 (1), pp. 29-63.

Rosie, M., MacInnes, J., Petersoo, M., Condor, S. and Kennedy, J. (2004) "Nation Speaking unto Nation? Newspapers and National Identity in the Devolved UK". Sociological Review, Vol.52 (4), pp.437-458.

Rosie, M., Petersoo, P., MacInnes, J., Condor, S. and Kennedy, J. (2006) "Mediating Which Nation? Citizenship and National Identities in the British Press". Social Semiotics, Vol. 16 (2), pp.327-344.

Scammel, M. and Harrop, M. (2002) 'The Press Disarmed'. In: Butler, D. and Kavanagh, D., The British General Election of 2001. Basingstoke: Palgrave.

Schlesinger, P. (1998) 'Scottish Devolution and the Media'. In: Seaton, J. ed. Politics and the Media in Britain. Oxford: Blackwell.

Smith, M. (1994) Paper Lions: The Scottish Press and National Identity. Edinburgh: Polygon.

Tolson, A. (1996) Mediations: Text and Discourse in Media Studies. London: Arnold.

VanDijk, T. A. (1983) "Discourse Analysis: Its Development and Application to the Structure of News". Journal of Communication, 33 (2): 20-43.

VanDijk, T. (2001) "Multidisciplinary CDA: A Plea for Diversity". In Wodak, R. and Meyer, M. (eds) Methods of Critical Discourse Analysis. London, Sage.

Wodak, R. (2001) "What CDA Is About - A Summary of Its History, Important Concepts and Its Developments". In Wodak, R. and Meyer, M. (eds) Methods of Critical Discourse Analysis. London: Sage.

Wodak, R., DeCillia, R., Reisigl, M. and Liebhart, K. (1999) The Discursive Construction of National Identity. Edinburgh: Edinburgh University Press. 